\title{
A Study on Mobile banking Financial Transaction of Major Nationalized Banks in India
}

\author{
Krishna Prasad K. ${ }^{1} \&$ P. Ushadevi ${ }^{2}$ \\ ${ }^{1}$ Assistant Professor, College of Computer and Information Sciences, Srinivas University, \\ Mangaluru-575001, Karnataka, INDIA \\ ${ }^{2}$ Lecturer, College of Computer and Information Sciences, Srinivas University, Mangaluru- \\ 575001, Karnataka, INDIA \\ Email: karanikrishna@gmail.com
}

Type of the Paper: Research Paper.

Type of Review: Peer Reviewed.

Indexed in: OpenAIRE.

DOI: http://doi.org/10.5281/zenodo.1481300.

Google Scholar Citation: IJMTS

\section{How to Cite this Paper:}

Krishna Prasad, K., \& Ushadevi, P. (2018). A Study on Mobile banking Financial Transaction of Major Nationalized Banks in India. International Journal of Management, Technology, and Social Sciences (IJMTS), 3(2), 100-119.

DOI: $\underline{\text { http://doi.org/10.5281/zenodo.1481300. }}$

International Journal of Management, Technology, and Social Sciences (IJMTS)

A Refereed International Journal of Srinivas University, India.

(C) With Authors.

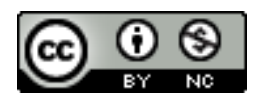

This work is licensed under a Creative Commons Attribution-Non Commercial 4.0 International License subject to proper citation to the publication source of the work.

Disclaimer: The scholarly papers as reviewed and published by the Srinivas Publications (S.P.), India are the views and opinions of their respective authors and are not the views or opinions of the SP. The SP disclaims of any harm or loss caused due to the published content to any party. 


\title{
A Study on Mobile banking Financial Transaction of Major Nationalized Banks in India
}

\author{
Krishna Prasad K. ${ }^{1}$ \& P. Ushadevi ${ }^{2}$ \\ ${ }^{1}$ Assistant Professor, College of Computer and Information Sciences, Srinivas University, \\ Mangaluru-575001, Karnataka, INDIA \\ ${ }^{2}$ Lecturer, College of Computer and Information Sciences, Srinivas University, Mangaluru- \\ 575001, Karnataka, INDIA \\ Email: karanikrishna@gmail.com
}

\begin{abstract}
Adopting new technology in the banking sector is very useful for the growth of banks in India. The bank is the main financial institution that provides the digital technology-enabled services to the customers in an effective manner. Because of competition today each and every bank is providing modern and innovative services to attract a number of customers. Mobile banking (also known as M-banking) is latest technology or novel technology, user-friendly, and widely used concept in Electronic banking that is used to accomplish cashless financial transactions, fund transfer, credit applications and payment of bills, taxes etc. remotely through mobile devices like smartphones, PDAs, and tablets. The uncommon increment in the utilization of mobile phones in both urban and rural areas provides exciting opportunities for the development of cell phone based banking. But in India, a developing country, mobile banking is limited to only some fields such as SMS due to lack of facilities, security issues, poorly performing internet connections and because of high priced. In this paper, we present a comparative study on Mobile Banking transaction of major banks in India. In this paper, we analyzed and discussed portable banking money/financial transactions, using ABCD analysis and based on the analysis we made a few proposals/recommendations to cell-phone enabled banking service contributor. This will encourage the scientist/researcher to find the gap between the traditional and digital method of financial transactions in India.
\end{abstract}

Keywords: M-banking, Digital technology, ABCD Analysis, Financial Transactions, Wireless Communication Technology.

\section{INTRODUCTION :}

The brisk or quick improvement of the portable media transmission industry alongside remote innovation and web made another correspondence innovation named as $4 \mathrm{G}$ or Fourth Generation with properties as speed or tweaked/customized administrations/services, interactive multimedia and sound, predominant quality video, and quick broadband web [1-3]. Versatile/cell-phone banking is a basic, sheltered and quick service given by banks or other money related establishment which enables its clients to direct monetary exchanges remotely utilizing a cell phone. At first the dominant part of banks began with only short message service based banking services to drive the transaction messages to the customer. After the evolution of smartphones, various operating systems to mobile phones and many apps, the Bank and other financial institutions adopted some of the new technologies like fund transfer, utility bill payments, ticket booking, mobile/DTH recharge etc [4-10]. Real Banks have created a portable application which encourages bank's customers to get account clarifications as passbook and other transaction details with the assistance of their advanced cells/tablets whenever it might suit them without visiting the Banks. It's a 
convenient way to access account details while on the move. Fourth Generation (4G) remote portable innovation structure is a latest remote electronic gadget standard with features like improved data conversion scale, high security, modified and unavoidable administrations /services, smart intuitive media, voice, video, remote web and other broadband services with quick and effective [11]. This 4G technology can be affectively used in order to successfully implement and deliver mobile banking services worldwide. Cell-phone based banking (mmanaging an account) is seen as one of the most recent internet and mobile enabled money services to its clients. Despite the fact that Automated Teller Machine (ATM), phone, and Internet based banking are managing an account benefits outside the banks and offers effective conveyance channels for customary money, versatile/cell-phone banking is the most up to date circulation channels built up by the banks in many developed and developing nations with more accentuation on omnipresent nature of administration accessibility [12]. A German organization Paybox in a joint effort with Deutsche Bank at first propelled cell-phone based banking in late 1990. Initially decade of the 21 century, some developing nations began presenting cell-phone based banking benefits in that Kenya was the main developing nation presented m-managing an account benefit with more importance on everywhere available services called M-Pesa, in 2007.

In the current system of cell-phone banking just client/user name and secret password or One Time Password (OTP) is regularly utilized for verification purposes. Security is the one of greatest worry for the across the board utilization of cell-phone based banking account money services. As number of cell-phone user clients increments quickly and exponentially, a solid confirmation instrument winds up basic. Location data can be utilized as one of the factor of validation/authentication purpose. In Location Authentication recover client's present area and further process that information to get more data close to their present area and to validate against person's asserted personality. All together gain area data iBeacon or GPS can be viably utilizing relying upon the separation inclusion factor. Location based validation is the exceptional strategy to demonstrate singular people character or legitimacy on by distinguishing or identifying client nearness at a different areas utilizing a few images, unique highlights or utilizing extraordinary items. Location based verification can be affectively connected with the end goal to benefit propelled services to clients, which incorporates a few services like Digital Deposit, Mini loan services, Advanced ATM Security, Advanced Bill Payment, Credit Card Security and Auxiliary Services.

This paper contains six segments. Segment 1 portrays starting introduction of cell-phone based banking services. Section 2 clarifies related research of cell-phone based banking money transactions and it additionally covers few difficulties looked by portable saving money services like securities. Section 3 depicts research objectives and methods, which knows the commitment made by this paper to other research networks. Segment 4 portrays diverse money related exchanges and services of versatile keeping money in real open division banks of India with its highlights. Area 5 makes Analysis of cell-phone based baking's account money related exchanges utilizing ABCD analysis and based on the examination and we additionally make a few suggestions to cellphone based banking service contributor. Segment 6 finishes up the paper through conclusion. This will assist the researcher with finding the research gap between the customary and advanced cell-phone based banking services in India.

\section{RELATED RESEARCH :}

In literature, many related examinations are accessible, which for the most part centers around conceptual study on cell-phone based banking services. Specialists utilized different terms for portable/cell-phone banking services, Amin et al., (2006) alluded cell-phone managing an account as pocket keeping banking, Ivatury and Mas, (2008) as branchless banking system, while Donner and Tellez, (2008) called minstallments, m-exchanges, m-fund and Liu et al., (2009) named as m-banking [13-16]. 
Veijalainen et al., (2006) contend, the principle main thrust for the quick acknowledgment of little cell phones is because of the capacity they offer for acquiring services and running applications at whatever point, anyplace or universally or even while progressing or moving [17]. Shaikh, (2013) expressed in his exploration that the expanded and sensational utilization of PDAs provoked numerous money related foundations or banks and specialist organizations to present cell-phone based banking services with an account benefits alongside some non-monetary exchange to broaden their customer reach with the intension to hold and fulfill existing clients, obtain new clients, enhance their incomes and to give new business openings [18]. Mari Suoranta et al., (2003) concentrated on their exploration on examining dispersal and adopters of cell-phone based banking services. They made an observational study on these new type of banking services and discovered that specific statistic trademark and the favored correspondence method of clients, effects on the reception and future use of cell-phone based banking services [19]. Jukka Riivari, (2005) expressed that cell-phone based banking services as an intense advertising apparatus to manufacture continuous and commonly remunerating association with new and existing clients and this qualities was the explanation behind financial institutions crosswise over Europe to exploit cell-phone based banking services [20]. Mari Suoranta et al., (2005) reviews that new technological advances in banking sector will act as driving force for mobile banking services adoption. Based on empirical inference of the study, the paper proposes a model based on conceptual theory, aggregates different factors affecting the mobile banking [21]. The exploratory study of Vijayan et al., (2005) [22] examines the consumer's intention to adopt mobile banking services or any new services based on three commonly used theories as Technology Acceptance Theories (TAT). This examination gets more significance because of the factor that money related organizations are confronting gigantic test to draw in guests to their site and consequently profiting new services and new learning or hypothesis can assist investors with fishing or pull in more customers into cell-phone based banking services.

Lee et al., (2003) [23] performed eight meetings to gather records from members and presumed that there are a few elements which are viewed as positive and negative state of mind for reception of portable managing an account, in which relative favorable circumstances and similarity were affecting elements and seen hazard and customer past experience was non impacting factors.

Thakur, R., and Srivastava, M. (2014) [24] arranged an exploration paper with an aim to discover useful reliance or connection between adoption readiness (AR), seen hazard and use intention of cell-phone helped payment framework in India and furthermore to know the created model dauntlessness of organized association with various clients gathering. In their proposed model, five out of six speculations was completely bolstered dependent on various supporting builds and then again one theory was mostly upheld Nayak, Nath, and Goel (2014) [25] arranged a paper with an intention to know or investigate distinctive elements that impact or bolster the acceptance characteristics or practices Indian clients for encountering cell-phone based banking services and paper additionally makes diverse suggestions for portable saving money administrations suppliers to improve cell-phone based banking services to hold their current clients and to obtain new clients.

Jain, J. (2013) [26] utilized an irregular/random sampling of 100 individuals in Rajasthan of India, with the end goal to distinguish factors affecting the acceptance and use of cell-phone based banking benefits by Customers in Southern Rajasthan. He discovered that shoppers are not kidding about the danger of directing managing an account by means of a remote channel, estimated as far as generally security and dependability of the services advertised. Notwithstanding, due to different issues in $\mathrm{m}$ keeping money framework, this isn't generally acknowledged by South Rajasthan bank client. He likewise discovered that customers get 
discouraged by the confused capacities while getting to the mobile managing an account services which lead them to the disappointment level as no appropriate direction is to be given to them [26]. Sathye, M. (1999) and Mattila, M. (2001) have contended that one of the greatest obstructions for the development of on the web or additionally cell-phone banking framework is complex security instrument. In mobile banking transactions confidentiality of traffic, of location and of the communicating parties address are important for privacy [27-28].

\section{RESEARCH OBJECTIVE AND} METHODOLOGY :

The main objectives of the research are given below.

- To study cell-phone based banking framework's money related transactions of major prominent Banks in India which includes private and public sector Banks.

- To analyze cell-phone based banking framework's money related transactions using ABCD Analysis

- Based on the analysis recommendations on mobile banking services.

Methodology of the examination depends on Banks official website analysis and research results are dependent on investigation of public sector Banks site and suggestions dependent on the investigation.

\section{MOBILE BANKING FINANCIAL TRANSACTIONS OF MAJOR PUBLIC SECTOR BANKS IN INDIA :}

In order to realize the true benefits of mobile banking and to effectively implement it, fast accessible, without delay, web associations are specifically accessible to all locations without any restriction in location place and time. A number of existing or future technologies that enable connections between mobile devices and other information appliances and between mobile devices and the Internet are through the series or generation of $1 \mathrm{G}, 2 \mathrm{G}, 3 \mathrm{G}, 4 \mathrm{G}$ and upcoming $5 \mathrm{G}$ technologies. As the mobile communication technology moved from generations to generations speed, broadband capacity, bandwidth, availability increased. Fourth Generation (4G) technology is characterized by advanced personalization, high speed, all IP-based, high speed, ubiquitously available services. Table 1 describes the different facilities available for financial transaction using mobile in major public sector banks in India. Table 2 shows fund transfer limits of various nationalized Banks in India.

Table 1: Facilities available in Major Nationalized Banks in India

\begin{tabular}{|c|c|c|c|}
\hline Sl. No & Bank name & Facilities available & Mobile Bank App \\
\hline 1. & $\begin{array}{l}\text { State Bank of } \\
\text { India }\end{array}$ & $\begin{array}{ll}\text { - } & \text { Funds transfer (within and outside the bank) } \\
\text { - } & \text { Immediate Payment Services (IMPS) } \\
\text { - } & \text { Enquiry services (Balance enquiry/ Mini } \\
\text { - } & \text { Chequement) } \\
\text { - } & \text { Demat Enquiry Service } \\
\text { - } & \text { Bill Payment (Utility bills, credit cards, } \\
\text { - } & \text { Insurance premium), } \\
\text { - } & \text { Monations, Subscriptions } \\
\text { - } & \text { M Commerce (Merchant payments, SBI life } \\
\text { - } & \text { insurance premium) } \\
\text { - } & \text { Mobile Banking Service over SMS } \\
& \text { (Unstructured Supplementary Service Data) }\end{array}$ & State Bank Anywhere \\
\hline
\end{tabular}


International Journal of Management, Technology, and Social

\begin{tabular}{|c|c|c|c|}
\hline 2. & Andhra Bank & $\begin{array}{ll}\text { - } & \text { Balance Inquiry } \\
\text { - } & \text { Mini Statement } \\
\text { - } & \text { Funds Transfer } \\
\text { - } & \text { Mobile Recharge /DTH. } \\
\text { - } & \text { Utility Bill Payments } \\
\text { - } & \text { Credit card Services } \\
\text { - } & \text { Cheque Services }\end{array}$ & Abtej \\
\hline 3. & $\begin{array}{l}\text { Allahabad } \\
\text { Bank }\end{array}$ & $\begin{array}{ll}\text { - } & \text { Balance check } \\
\text { - } & \text { Fund Transfer } \\
\text { - } & \text { IMPS, ALL payments } \\
\text { - } & \text { Balance Enquiry } \\
\text { - } & \text { Mini Statement: } \\
\end{array}$ & mPay, Allmobile \\
\hline 4. & $\begin{array}{l}\text { Bank of } \\
\text { Baroda }\end{array}$ & $\begin{array}{ll}\text { - } & \text { Fund transfer } \\
\text { - } & \text { Recharge \& Bill pay Mobile recharge, DTH } \\
\text { recharge, Data card recharge, Utility bill } \\
\text { payment, Credit Card (BOB card) payment, } \\
\text { Bharat Bill Payment System } \\
\text { - } \quad \begin{array}{l}\text { Account Balance- Mini statement-360 degree } \\
\text { view of account. } \\
\text { - Cheque book request, Stop Cheque, Cheque } \\
\text { status enquiry }\end{array}\end{array}$ & mConnect-Plus \\
\hline 5. & Canara Bank & $\begin{array}{ll}\text { - } & \text { Balance enquiry, } \\
\text { - } & \text { Mini statement, } \\
\text { - } & \text { Intra bank funds transfer and interbank funds } \\
\text { transfer through IMPS }\end{array}$ & CanMobile \\
\hline 6. & $\begin{array}{l}\text { Corporation } \\
\text { Bank }\end{array}$ & $\begin{array}{ll}\text { - } & \text { Instant Term Deposit /RD opening } \\
\text { - } & \text { Instant Blocking and Unblocking of Debit Card } \\
\text { - } & \text { Detailed view of your Account with latest } \\
\text { - } & \text { balance \& Mini statement. } \\
\text { - } & \text { Fund transfer. } \\
\text { - } & \text { Status inquiry of Cheque } \\
\text { - } & \text { Stop cheque } \\
\text { - } & \text { Account statement on email (in pdf format) } \\
\text { - } & \text { Foreign currency exchange rates } \\
\text { - } & \text { Transaction History view \& Transaction } \\
\text { - } & \text { complaint Management } \\
\text { - } & \text { Accuest for New Savings Account, Current } \\
\text { - } & \text { Branch \& ATM Locatl payment using Bharat Bill Payment } \\
& \text { System (BBPS) } \\
\end{array}$ & Corp EASE \\
\hline 7. & Union Bank & $\begin{array}{ll} & \text { Balance Enquiry } \\
\text { - } & \text { Mini Statement (last nine transactions) } \\
\text { - } & \text { Fund Transfer } \\
\text { IMPS Fund transfer using Mobile No. and } \\
\text { MMID }\end{array}$ & UMobile \\
\hline
\end{tabular}




\begin{tabular}{|c|c|c|c|}
\hline & & $\begin{array}{ll}\text { - } & \text { IMPS Fund transfer using Account No. and IFSC } \\
\text { - } & \text { IMPS Fund transfer using Aadhaar No. } \\
\text { - } & \text { Merchant IMPS Fund transfer } \\
\text { - } & \text { KVS Fee Payment } \\
\text { - } & \text { Mobile Recharge } \\
\text { - } & \text { Temple Donations } \\
\text { - } & \text { Fees payments } \\
\text { - } & \text { Stop Payment of cheques } \\
\text { - } & \text { Cheque status } \\
\text { - } & \text { Hotlist Debit Card } \\
\text { - } & \text { ATM/Branch Locator } \\
\text { - } & \text { Request to Bank for Cheque Book } \\
\end{array}$ & \\
\hline 8. & $\begin{array}{l}\text { Syndicate } \\
\text { Bank }\end{array}$ & $\begin{array}{ll}\text { - } & \text { Fund transfer using IMPS } \\
\text { - } & \text { Fund transfer within Syndicate Bank accounts } \\
\text { - } & \text { Debit card management } \\
\text { - } & \text { Value added services and bill payment } \\
\text { - } & \text { Balance Enquiry and Mini Statement } \\
\text { - } & \text { SMS and Email Statement Registration } \\
\text { - } & \text { Aadhaar Seeding } \\
\text { - } & \text { Request for Cheque book } \\
\text { - } & \text { View issued cheque status and Stop cheque } \\
& \text { payment }\end{array}$ & Synd Mobile \\
\hline 9. & $\begin{array}{l}\text { Indian } \\
\text { Overseas } \\
\text { Bank }\end{array}$ & $\begin{array}{ll}\text { - } & \text { Balance Enquiry } \\
\text { - } & \text { Mini Statement } \\
\text { - } & \text { Fund Transfer } \\
\text { - } & \text { Bill payments } \\
\text { - } & \text { Cheque requests, Stop cheque, cheque status } \\
\text { - } & \text { ATM Card blocking } \\
\text { - } & \text { Foreign Inward Remittance using IMPS }\end{array}$ & IOBMobile \\
\hline 10. & $\begin{array}{l}\text { Punjab } \\
\text { National } \\
\text { Bank }\end{array}$ & $\begin{array}{ll}\text { - } & \text { View account transactions any time. } \\
\text { - Fast and easy recharge and bill-payment } \\
\text { options. } \\
\text { SMS Banking, USSD Banking or Missed Call } \\
\text { Banking. } \\
\text { - Payments mobility solutions for accepting cards. } \\
\text { Accepts Rupay, VISA, Master, AMEX, } \\
\text { DINERS. }\end{array}$ & PNB Mobile \\
\hline
\end{tabular}

Table 2: Fund transfer limits of various nationalized Banks in India.

\begin{tabular}{|l|l|}
\hline Bank Name & Fund Transfer limit \\
\hline State Bank of & $\begin{array}{l}\text { Unlimited Funds Transfer Facility: SBI Freedom allows users to transfer funds with no } \\
\text { monthly limit. The daily combined limit for funds transfer through IMPS (Immediate } \\
\text { Payment Service) is Rs. 99,99,999. However, users can transfer only up to Rs. 50,000 } \\
\text { per day in other banks using the application. }\end{array}$ \\
\hline
\end{tabular}


International Journal of Management, Technology, and Social

\begin{tabular}{|c|c|}
\hline Andhra Bank & $\begin{array}{l}\text { Per day limit is Rs 2, 00,000/- through App including all type of transaction done } \\
\text { through application. } \\
\text { Rs 5000/- per transaction for quick pay. }\end{array}$ \\
\hline $\begin{array}{l}\text { Allahabad } \\
\text { Bank }\end{array}$ & Fund transfer Maximum Rs. 50000/- per transaction \& Maximum Rs. 1 lakh per day. \\
\hline $\begin{array}{l}\text { Bank of } \\
\text { Baroda }\end{array}$ & The transaction limits are Rs.50,000 per day and Rs.2.5 lakhs per month. \\
\hline Canara Bank & Transaction limit: 50,000 per day, 5 lakh for neft/RTGS \\
\hline $\begin{array}{l}\text { Corporation } \\
\text { Bank }\end{array}$ & $\begin{array}{l}\text { Within Bank Transfer : No Limit } \\
\text { Third Party Within Bank/IMPS/NEFT : } \\
\text { Max amount per transaction : RS 1,00,000/- } \\
\text { Max amount per day: Rs 1,00,000/- } \\
\text { Cumulative fund transfer per day: Rs 1,00,000/- }\end{array}$ \\
\hline Union Bank & $\begin{array}{l}\text { A maximum of Rs. 2,00,000/day via the UMobile application and Rs. 5000/day using } \\
\text { SMS Banking. }\end{array}$ \\
\hline $\begin{array}{l}\text { Syndicate } \\
\text { Bank }\end{array}$ & $\begin{array}{l}\text { Maximum of Rs.5,000/- per-day/per-customer, if transaction is initiated through } \\
\text { SMS/IVR or NUUP platform. Maximum of Rs.50,000/- per-day/per-customer, if } \\
\text { transaction is initiated through downloaded application. The cumulative limit is capped } \\
\text { at Rs.50,000/- per-day/per-customer. }\end{array}$ \\
\hline $\begin{array}{l}\text { Indian } \\
\text { Overseas } \\
\text { Bank }\end{array}$ & Customers can transfer up to Rs.50,000/- in a single day. \\
\hline $\begin{array}{l}\text { Punjab } \\
\text { National } \\
\text { Bank }\end{array}$ & $\begin{array}{l}\text { Rs. 50,000/- per day. However, through SMS \& NUUP variants, limit is Rs.5000/- per } \\
\text { day and through ATMs limit is Rs.10000/- per day. }\end{array}$ \\
\hline
\end{tabular}

5. ANALYSIS OF MOBILE BANKING FINANCIAL TRANSACTIONS OF MAJOR PUBLIC SECTOR BANKS IN INDIA USING ABCD ANALYSIS :

As opposed to PC, portable individual gadgets, normally with a settled presentation and console, are very much situated to give a useful answer for diminishing extortion and permitting the reasonable distribution of duty regarding pay from misrepresentation. Some measure of security is as of now part of the verification system of existing cell phones as an approach to forestall call burglary through password and subscriber identification module (SIM). Also, it is moderately simple and cheap for cell-phone makers to include extra components to guarantee safe transaction authorization. Public sector banks of India furnish monetary exchanges through cell-phone based banking system with security highlights username, secret password and OTP. The investigation of cell-phone based monetary exchange services of public sector banks in India is analyzed utilizing Advantages, Benefits, Constraints, and Disadvantages.

About ABCD Analysis: Many techniques are available in the writing of research papers, to examine the individual qualities, system traits, and effectiveness of an idea or concept, the effectiveness of a method to know its merits and negative marks and furthermore business esteem in the general public. The individual traits or organizational effectiveness \& techniques in a given surroundings may be studied the usage of SWOT analysis, SWOC evaluation, PEST analysis, McKinsey7s framework, ICDT version, Portor's 5 force model and so on. Recently a new model is introduced to these analysis areas called ABCD analysis framework [29], which is utilized for dissecting business, business system, new technology, new model, new idea/concept etc. In the qualitative evaluation the use of ABCD framework, the new idea or new system or new strategy or new generation or new model or new concept is further analyzed studied or analyzed using 
critical constituent elements. In the quantitative evaluation the use of ABCD framework [30], can be utilized to assign appropriate score or rating for each critical constituent elements, which is calculated through empirical research. The final score is calculated and based on the score the new idea or new system or new strategy or new generation or new model or new concept can be accepted or rejected. Consequently, ABCD evaluation framework may be used as a research tool in these regions and is easy but systematic study or analyzing method is essential for business concept or systems or models or ideas or strategy evaluation [29-46].

The ABCD analysis effects in an organized listing of Business or new Model with reward (advantages), Benefits, Restriction/Constraints, and drawbacks/Disadvantages in a systematic way or form. The complete framework is divided into various issues, the area which new model is focused. Different key properties and influencing the territory of the new model might be distinguished and broke down under every region of issues recognized previously. Later some of the critical constituent element for each identified issue is recognized and analyzed and which is shown in Figure 1. This framework of examination is simple and also offers a guideline to identify and examine the effectiveness of the new model in this context. As per ABCD analysis various determinant issues related to Mobile Banking Financial Transactions are: (1) Security issues, (2) User-friendly issues, (3) Process issues [46].

(1) Security Issues :

Security is very important in the Mobile Banking Financial Transactions. An ideal security refers that a system which is impossible for an intruder to break or access the system. In the Authentication process, security refers safeguarding the user personal data used for the authentication process, which includes Password, and One Time Password (OTP. The affecting factors of Security issues include Password, and OTP under key properties or levels like user level, network level, and Database level are determinant factors under the constructs Advantages, Benefits, Constraints, and Disadvantages of the new model.

(2) User-friendly Issues :

The user-friendliness of Mobile Banking transactions means that client should ready to gain admittance to the framework easy or effectively without recalling that anything or exceptionally least measure of information. The affecting factors under key properties like Response time, Access time, Automatic Process, Speed, and Availability are determinant factors under the constructs Advantages, Benefits, Constraints, and Disadvantages of the new model.

(3) Process Issues :

Process Issues ensures that client should ready to complete authentication process without any fault, fast and completely. The affecting factors under key properties like Atomicity, Consistency, Isolation, Availability, effort free, and High durability are determinant factors under the constructs Advantages, Benefits, Constraints, and Disadvantages of the new model.

Every determinant issue has sub-issues called key characteristics utilized for breaking down the favorable circumstances, advantages, limitations and impediments; the four develops of the structure. The variables influencing the different determinant issues of Mobile Banking Financial Transactions for each key property inside four builds are inferred by a subjective information gathering instrument to be specific, center gathering technique and are recorded in Table 3. 
ADVANTAGES

BENEFITS
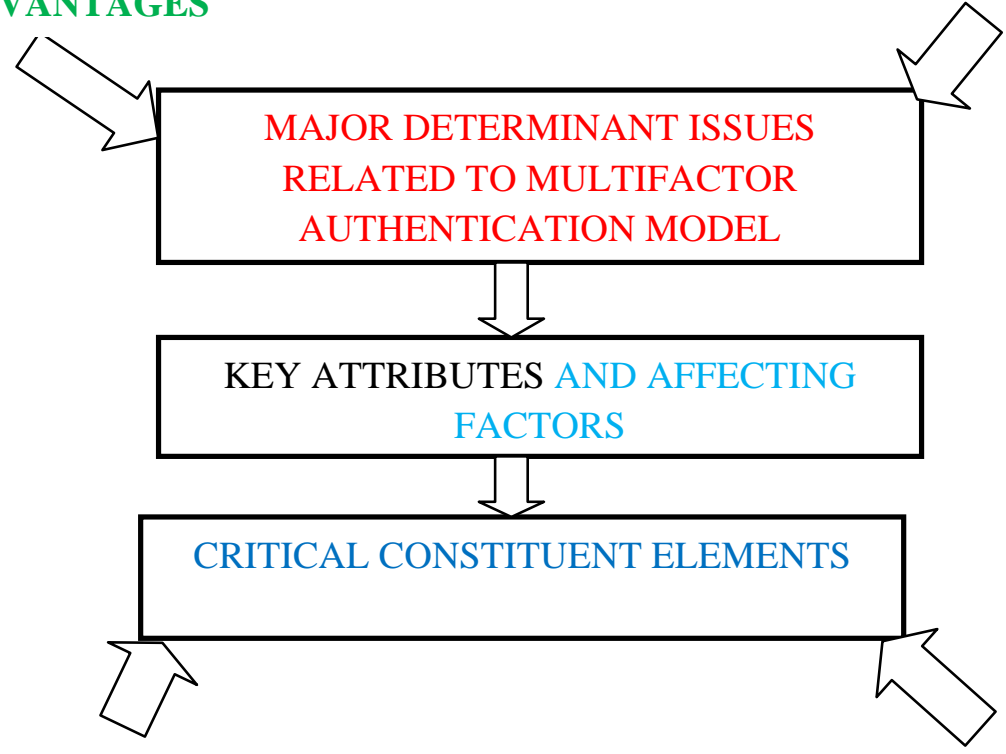

CONSTRAINTS

DISADVANTAGES

Figure 1: Block diagram of Issues affecting the Mobile Banking Financial Transactions

Table 3: Analysis of Mobile Banking Financial Transactions

\begin{tabular}{|c|c|c|c|c|c|}
\hline $\begin{array}{l}\text { Determina } \\
\text { nt Issues }\end{array}$ & $\begin{array}{l}\text { Key } \\
\text { Attributes }\end{array}$ & Advantages & Benefits & Constraints & Disadvantages \\
\hline \multirow[t]{3}{*}{$\begin{array}{l}\text { Security } \\
\text { Issues }\end{array}$} & $\begin{array}{l}\text { User level } \\
\text { security }\end{array}$ & $\begin{array}{l}\text { Easy to } \\
\text { safeguard using } \\
\text { lock pattern, } \\
\text { lock based on } \\
\text { image, pin } \\
\text { based lock for } \\
\text { mobile phone }\end{array}$ & $\begin{array}{l}\text { increases } \\
\text { demand of } \\
\text { smart Mobile, } \\
\text { new type of } \\
\text { pattern lock or } \\
\text { mobile lock } \\
\text { softwares }\end{array}$ & $\begin{array}{l}\text { High Security } \\
\text { of the cell- } \\
\text { phone based } \\
\text { banking } \\
\text { transactions } \\
\text { are } \\
\text { questionable }\end{array}$ & $\begin{array}{l}\text { Acceptance by } \\
\text { the user }\end{array}$ \\
\hline & $\begin{array}{l}\text { Network } \\
\text { Level } \\
\text { Security }\end{array}$ & $\begin{array}{l}\text { Non- reversible, } \\
\text { Non- Revocable } \\
\text { Hash code, }\end{array}$ & $\begin{array}{lr}\text { Customer } & \text { faith } \\
\text { increases } & \text { Can } \\
\text { attract } & \text { new } \\
\text { customer } & \end{array}$ & $\begin{array}{ll}\text { tampering of } \\
\text { data }\end{array}$ & $\begin{array}{l}\text { Network failure } \\
\text { due to some } \\
\text { uncontrollable } \\
\text { circumstances }\end{array}$ \\
\hline & $\begin{array}{l}\text { Database } \\
\text { Security }\end{array}$ & $\begin{array}{ll}\text { Advanced } & \\
\text { encryption and } \\
\text { decryption } \\
\text { algorithm are } \\
\text { used } & \\
\end{array}$ & $\begin{array}{l}\text { Database is } \\
\text { easily } \\
\text { manageable }\end{array}$ & $\begin{array}{l}\text { Database table } \\
\text { requires } \\
\text { values in } \\
\text { encryption } \\
\text { form }\end{array}$ & $\begin{array}{l}\text { Database failure, } \\
\text { Server failure }\end{array}$ \\
\hline $\begin{array}{l}\text { User- } \\
\text { friendly } \\
\text { Issues }\end{array}$ & $\begin{array}{l}\text { Response } \\
\text { time }\end{array}$ & $\begin{array}{l}\text { Increased rate } \\
\text { of growth of } \\
\text { authentication } \\
\text { process }\end{array}$ & $\begin{array}{l}\text { Increased } \\
\text { customer pool }\end{array}$ & $\begin{array}{l}\text { Requires high } \\
\text { configuration } \\
\text { system and } \\
\text { efficient } \\
\text { algorithms }\end{array}$ & $\begin{array}{l}\text { Hardware and } \\
\text { Software cost }\end{array}$ \\
\hline
\end{tabular}

Krishna Prasad K. et al. (2018); www.srinivaspublication.com 
International Journal of Management, Technology, and Social

\begin{tabular}{|c|c|c|c|c|c|}
\hline & Access time & $\begin{array}{l}\text { User } \\
\text { Instantaneous } \\
\text { authentication }\end{array}$ & $\begin{array}{l}\text { Reduced } \\
\text { Queuing, } \\
\text { Reduced } \\
\text { waiting } \\
\text { process }\end{array}$ & $\begin{array}{l}\text { Requires good } \\
\text { network, } \\
\text { memory, and } \\
\text { processor }\end{array}$ & $\begin{array}{l}\text { Hardware and } \\
\text { software cost }\end{array}$ \\
\hline & Speed & $\begin{array}{l}\text { Increased } \\
\text { Authentication/ } \\
\text { Mobile banking } \\
\text { user request per } \\
\text { unit time }\end{array}$ & $\begin{array}{l}\text { Increased } \\
\text { customer } \\
\text { satisfaction, } \\
\text { retention and } \\
\text { acquiring new } \\
\text { customers } \\
\text { becomes easy }\end{array}$ & $\begin{array}{l}\text { Requires high } \\
\text { configured } \\
\text { system and } \\
\text { reduced time } \\
\text { complexity }\end{array}$ & $\begin{array}{l}\text { Hardware and } \\
\text { software cost, } \\
\text { High bandwidth } \\
\text { network, }\end{array}$ \\
\hline & $\begin{array}{l}\text { Automatic } \\
\text { process }\end{array}$ & $\begin{array}{l}\text { Minimum prior } \\
\text { information of } \\
\text { the system } \\
\text { required }\end{array}$ & $\begin{array}{l}\text { Increased } \\
\text { customer } \\
\text { satisfaction, }\end{array}$ & $\begin{array}{l}\text { Ability to } \\
\text { make } \\
\text { difference } \\
\text { between } \\
\text { registered and } \\
\text { unregistered } \\
\text { user, } \\
\text { processing } \\
\text { power }\end{array}$ & $\begin{array}{l}\text { Utilization of the } \\
\text { hardware and } \\
\text { software } \\
\text { resources are too } \\
\text { high } \\
\text { complex backend } \\
\text { design of user } \\
\text { interface }\end{array}$ \\
\hline & Availability & $\begin{array}{l}\text { Ubiquitous } \\
\text { authentication }\end{array}$ & $\begin{array}{l}\text { Reduced } \\
\text { request queue }\end{array}$ & $\begin{array}{l}\text { Dedicated } \\
\text { server and } \\
\text { network }\end{array}$ & $\begin{array}{l}24 \times 7 \text { working } \\
\text { server }\end{array}$ \\
\hline \multirow[t]{5}{*}{$\begin{array}{l}\text { Process } \\
\text { Issues }\end{array}$} & Atomicity & $\begin{array}{l}\text { Authentication } \\
\text { process } \\
\text { Rollback or } \\
\text { Commit at the } \\
\text { time of system } \\
\text { failure }\end{array}$ & $\begin{array}{l}\text { Authentication } \\
\text { failure is very } \\
\text { rare or } \\
\text { practically } \\
\text { zero. }\end{array}$ & $\begin{array}{l}\text { Need of good } \\
\text { fault tolerance } \\
\text { techniques. }\end{array}$ & $\begin{array}{l}\text { Requires separate } \\
\text { programme for } \\
\text { database } \\
\text { protection } \\
\text { /safeguards }\end{array}$ \\
\hline & Consistency & $\begin{array}{l}\text { Ensures } \\
\text { consistent state } \\
\text { at the time of } \\
\text { system failure }\end{array}$ & $\begin{array}{l}\text { Authentication } \\
\text { process } \\
\text { ensures } \\
\text { consistency, }\end{array}$ & $\begin{array}{l}\text { Need of good } \\
\text { fault tolerance } \\
\text { techniques. }\end{array}$ & $\begin{array}{l}\text { Database } \\
\text { management and } \\
\text { safe guarding } \\
\text { requires extra } \\
\text { efforts and cost }\end{array}$ \\
\hline & Isolation & \begin{tabular}{l}
\multicolumn{2}{l}{ Authentication } \\
process gets \\
isolation \\
property
\end{tabular} & $\begin{array}{l}\text { Enhanced user } \\
\text { trust and } \\
\text { satisfaction }\end{array}$ & $\begin{array}{l}\text { Need for good } \\
\text { lock-based } \\
\text { concurrency } \\
\text { control system }\end{array}$ & $\begin{array}{l}\text { Database } \\
\text { management and } \\
\text { lock-based } \\
\text { concurrency } \\
\text { control requires } \\
\text { extra cost }\end{array}$ \\
\hline & Availability & $\begin{array}{l}\text { Ubiquitous } \\
\text { authentication }\end{array}$ & $\begin{array}{l}\text { Reduced } \\
\text { request queue }\end{array}$ & $\begin{array}{l}\text { Dedicated } \\
\text { server and } \\
\text { network }\end{array}$ & $\begin{array}{l}24 \times 7 \text { working } \\
\text { server }\end{array}$ \\
\hline & Effort free & $\begin{array}{l}\text { User freely and } \\
\text { easily interacts } \\
\text { with } \\
\text { authentication } \\
\text { system }\end{array}$ & $\begin{array}{l}\text { User enjoys } \\
\text { working with } \\
\text { system, } \\
\text { Increased } \\
\text { trust, user } \\
\end{array}$ & $\begin{array}{l}\text { Requires } \\
\text { navigational } \\
\text { and narrative } \\
\text { user interface, } \\
\text { Input should }\end{array}$ & $\begin{array}{l}\text { Complex design } \\
\text { of user interface } \\
\text { and programme } \\
\text { increases cost }\end{array}$ \\
\hline
\end{tabular}


International Journal of Management, Technology, and Social

\begin{tabular}{|l|l|l|l|l|l|}
\hline & & satisfaction & $\begin{array}{l}\text { be selective } \\
\text { rather than } \\
\text { enter }\end{array}$ & \\
\cline { 2 - 6 } & Duranged and & $\begin{array}{l}\text { Changed } \\
\text { Password and } \\
\text { Biometric-ID } \\
\text { durable for long } \\
\text { time }\end{array}$ & $\begin{array}{l}\text { Revocability be done } \\
\text { can be } \\
\text { easily, if } \\
\text { password or } \\
\text { finger-id is } \\
\text { compromised }\end{array}$ & $\begin{array}{l}\text { Need of good } \\
\text { fault tolerance } \\
\text { techniques. }\end{array}$ & $\begin{array}{l}\text { Database } \\
\text { management and } \\
\text { safeguarding } \\
\text { requires extra } \\
\text { efforts and cost }\end{array}$ \\
\hline
\end{tabular}

\section{SERIOUS INGREDIENT ELEMENTS AS PER ABCD MODEL :}

The important constituent factors of determinant issues are listed beneath the four constructs - advantages, benefits, constraints and disadvantages of the ABC model and tabulated in Tables 4 to 7.

Table 4: Advantages of Mobile Banking Financial Transactions

\begin{tabular}{|c|c|c|c|}
\hline $\begin{array}{l}\text { Sl. } \\
\text { No }\end{array}$ & Issue & Factors affecting & Serious Ingredient Elements \\
\hline \multirow[t]{4}{*}{1} & \multirow[t]{4}{*}{ Security Issues } & \multirow[t]{2}{*}{ Mobile/Smart Phone } & Structure of locking pattern \\
\hline & & & Password strength \\
\hline & & \multirow[t]{2}{*}{$\begin{array}{lll}\text { Techniques } & \text { used } & \text { for } \\
\text { authentication } & & \end{array}$} & $\begin{array}{l}\text { Password strength of mobile } \\
\text { banking service provider }\end{array}$ \\
\hline & & & $\begin{array}{l}\text { OTP complexity/structure of the } \\
\text { mobile banking service provider }\end{array}$ \\
\hline \multirow[t]{6}{*}{2} & \multirow[t]{6}{*}{$\begin{array}{l}\text { User-friendly } \\
\text { issues }\end{array}$} & \multirow[t]{3}{*}{$\begin{array}{l}\text { Increased rate of growth of } \\
\text { authentication process }\end{array}$} & $\begin{array}{l}\text { Time required for fetching password } \\
\text { and decrypting }\end{array}$ \\
\hline & & & Network speed for OTP \\
\hline & & & Speed of Matching function \\
\hline & & $\begin{array}{l}\text { Increased Authentication } \\
\text { request per unit time }\end{array}$ & Ability of concurrent authentication \\
\hline & & \multirow{2}{*}{$\begin{array}{l}\text { Ubiquitous authentication in } \\
\text { user-friendly issue }\end{array}$} & The system used for authentication \\
\hline & & & Availability of network \\
\hline \multirow[t]{11}{*}{3} & \multirow[t]{5}{*}{ Process Issues } & \multirow{2}{*}{$\begin{array}{l}\text { Authentication } \\
\text { Rollback or Commit at the } \\
\text { time of system failure }\end{array}$} & Strength of RDBMS \\
\hline & & & $\begin{array}{lll}\text { RDBMS transaction atomicity } \\
\text { property }\end{array}$ \\
\hline & & \multirow{2}{*}{$\begin{array}{l}\text { Ensures consistent state at the } \\
\text { time of system failure }\end{array}$} & Strength of RDBMS \\
\hline & & & $\begin{array}{lll}\text { RDBMS } & \text { transaction } & \text { consistent } \\
\text { property } & & \\
\end{array}$ \\
\hline & & $\begin{array}{l}\text { Authentication process gets } \\
\text { isolation property }\end{array}$ & Strength of RDBMS \\
\hline & & \multirow{3}{*}{$\begin{array}{l}\text { lsolation property } \\
\text { Ubiquitous authentication in } \\
\text { process issue }\end{array}$} & $\begin{array}{lll}\text { RDBMS } & \text { transaction } & \text { atomicity } \\
\text { property } & & \\
\end{array}$ \\
\hline & & & $\begin{array}{l}\text { The device used for authentication } \\
\text { process }\end{array}$ \\
\hline & & & Availability of network \\
\hline & & \multirow{2}{*}{$\begin{array}{l}\text { User freely and easily interacts } \\
\text { with authentication system }\end{array}$} & Simple user interface \\
\hline & & & Navigational and narrative interface \\
\hline & & Changed Password and OTP & Management and maintenance of \\
\hline
\end{tabular}


International Journal of Management, Technology, and Social

\begin{tabular}{|l|l|l|l|}
\hline & & durable for a long time & Database \\
\cline { 3 - 4 } & & Safeguarding of database \\
\hline
\end{tabular}

Table 5: Benefits of Mobile Banking Financial Transactions

\begin{tabular}{|c|c|c|c|}
\hline $\begin{array}{l}\text { Sl. } \\
\text { No }\end{array}$ & Issue & Factors affecting & Serious Ingredient Elements \\
\hline \multirow[t]{7}{*}{1} & \multirow[t]{7}{*}{ Security Issues } & $\begin{array}{l}\text { Increases demand Cloud } \\
\text { Drive, Mobile, Pen drive, and } \\
\text { laptop }\end{array}$ & $\begin{array}{l}\text { Usage of mobile phone for } \\
\text { authentication process }\end{array}$ \\
\hline & & \multirow{3}{*}{$\begin{array}{l}\text { Increased customer faith and } \\
\text { attracts new customer }\end{array}$} & Security in all aspects of network \\
\hline & & & Simple and easy way to input \\
\hline & & & $\begin{array}{l}\text { Time is taken for authentication } \\
\text { process }\end{array}$ \\
\hline & & \multirow[t]{3}{*}{$\begin{array}{l}\text { Efficient memory use, } \\
\text { Database is easily manageable }\end{array}$} & $\begin{array}{l}\text { One hash code for comparison and } \\
\text { matching }\end{array}$ \\
\hline & & & $\begin{array}{l}\text { Cryptographically Encrypted Hash } \\
\text { code }\end{array}$ \\
\hline & & & Non reversible Hash code \\
\hline \multirow[t]{16}{*}{2} & \multirow[t]{16}{*}{$\begin{array}{l}\text { User-friendly } \\
\text { issues }\end{array}$} & \multirow[t]{4}{*}{ Increased customer pool } & $\begin{array}{l}\text { Quality of multifactor authentication } \\
\text { model }\end{array}$ \\
\hline & & & Response time \\
\hline & & & Simple method of inputting \\
\hline & & & Speed of authentication process \\
\hline & & \multirow{3}{*}{$\begin{array}{lll}\text { Reduced Queuing } & \text { and } \\
\text { Reduced waiting process } & \end{array}$} & Good access time \\
\hline & & & Simple method of inputting \\
\hline & & & Speed of authentication process \\
\hline & & \multirow{4}{*}{ 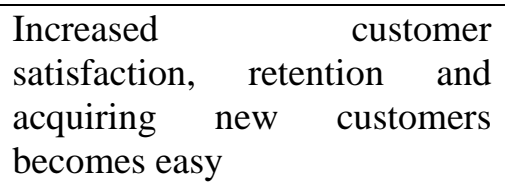 } & Good Access time \\
\hline & & & Good Response time \\
\hline & & & Simple method of inputting \\
\hline & & & Speed of authentication process \\
\hline & & \multirow{5}{*}{$\begin{array}{ll}\text { Increased } & \text { customer } \\
\text { satisfaction, } & \end{array}$} & Automatic process \\
\hline & & & Good Access time \\
\hline & & & Good Response time \\
\hline & & & Simple method of inputting \\
\hline & & & Speed of authentication process \\
\hline \multirow[t]{8}{*}{3} & \multirow[t]{8}{*}{ Process Issues } & \multirow{2}{*}{$\begin{array}{l}\text { Authentication failure is very } \\
\text { rare or practically zero. }\end{array}$} & Strength of RDBMS \\
\hline & & & $\begin{array}{l}\text { RDBMS transaction atomicity } \\
\text { property }\end{array}$ \\
\hline & & & $\begin{array}{l}\text { Ability of the system to handle } \\
\text { crashes or failures }\end{array}$ \\
\hline & & \multirow{3}{*}{$\begin{array}{l}\text { Ensures a safe state at the time } \\
\text { of system failure }\end{array}$} & Strength of RDBMS \\
\hline & & & $\begin{array}{l}\text { RDBMS transaction } \\
\text { property }\end{array}$ \\
\hline & & & $\begin{array}{l}\text { Ability of the system to handle } \\
\text { crashes or failures }\end{array}$ \\
\hline & & \multirow{2}{*}{$\begin{array}{l}\text { Enhanced user trust and } \\
\text { satisfaction }\end{array}$} & Strength of RDBMS \\
\hline & & & $\begin{array}{lll}\text { RDBMS } & \text { transaction } & \text { atomicity } \\
\text { property } & & \\
\end{array}$ \\
\hline
\end{tabular}

Krishna Prasad K. et al. (2018); www.srinivaspublication.com 


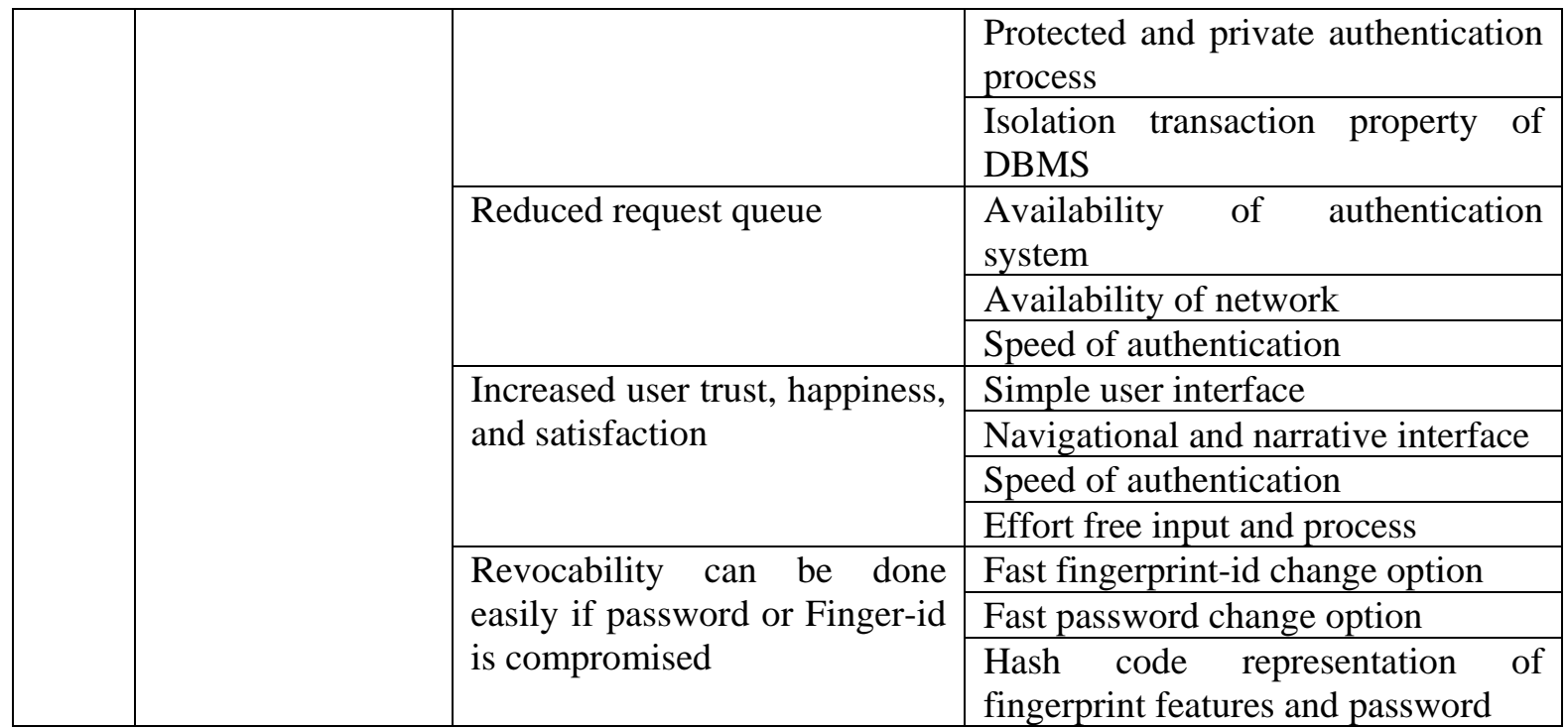

Table 6: Constraints of Mobile Banking Financial Transactions

\begin{tabular}{|c|c|c|c|}
\hline $\begin{array}{l}\text { Sl. } \\
\text { No }\end{array}$ & Issue & Factors affecting & Serious Ingredient Elements \\
\hline \multirow[t]{8}{*}{1} & \multirow[t]{8}{*}{ Security Issues } & $\begin{array}{l}\text { High Security of the Mobile } \\
\text { Phone is questionable }\end{array}$ & $\begin{array}{l}\text { Mobile phone pattern lock rigid } \\
\text { structure and strength of password }\end{array}$ \\
\hline & & \multirow[t]{5}{*}{ Good network architecture } & Connectivity and security \\
\hline & & & Redundancy \\
\hline & & & Standardization \\
\hline & & & Disaster recovery \\
\hline & & & Growth \\
\hline & & \multirow{2}{*}{$\begin{array}{l}\text { Cryptographically Hash } \\
\text { representation of username and } \\
\text { password }\end{array}$} & The strength of Hash code. \\
\hline & & & $\begin{array}{l}\text { The rate of difficulty for decrypting } \\
\text { Hash code. }\end{array}$ \\
\hline \multirow[t]{13}{*}{2} & \multirow{13}{*}{$\begin{array}{l}\text { User friendly } \\
\text { issues }\end{array}$} & \multirow{6}{*}{$\begin{array}{lrr}\text { Requires } & \text { high } & \text { configuration } \\
\begin{array}{l}\text { system } \\
\text { algorithms }\end{array} & \text { and } & \text { efficient } \\
\end{array}$} & RAM size \\
\hline & & & OS and its architecture (32bit 0r 64-bit) \\
\hline & & & Processor used \\
\hline & & & Single processor/ Multiprocessor \\
\hline & & & Clock speed \\
\hline & & & $\begin{array}{l}\text { Time and space complexity of } \\
\text { algorithms used. }\end{array}$ \\
\hline & & \multirow{5}{*}{$\begin{array}{l}\text { Ability to make difference } \\
\text { between registered and un- } \\
\text { registered user and Processing } \\
\text { power }\end{array}$} & $\begin{array}{l}\text { The features used for identification } \\
\text { purpose }\end{array}$ \\
\hline & & & RAM size \\
\hline & & & Processor used, Clock speed \\
\hline & & & Single processor/ Multiprocessor \\
\hline & & & $\begin{array}{l}\text { Time and space complexity of } \\
\text { algorithms used. }\end{array}$ \\
\hline & & \multirow[t]{2}{*}{$\begin{array}{l}\text { Dedicated server and network } \\
\text { in user-friendly issue }\end{array}$} & $\begin{array}{l}\text { All the features of server required for } \\
\text { efficiency }\end{array}$ \\
\hline & & & $\begin{array}{l}\text { All the features of network required for } \\
\text { efficiency }\end{array}$ \\
\hline
\end{tabular}


International Journal of Management, Technology, and Social

\begin{tabular}{|c|c|c|c|}
\hline \multirow[t]{8}{*}{3} & \multirow[t]{8}{*}{ Process Issues } & \multirow{4}{*}{$\begin{array}{l}\text { Need of good fault tolerance } \\
\text { techniques. }\end{array}$} & Strength of RDBMS \\
\hline & & & $\begin{array}{l}\text { RDBMS transaction's atomicity, } \\
\text { consistency, and isolation property }\end{array}$ \\
\hline & & & $\begin{array}{l}\text { The fault tolerance technique used in } \\
\text { RDBMS. }\end{array}$ \\
\hline & & & $\begin{array}{l}\text { The strength of lock based concurrency } \\
\text { control used in RDBMS }\end{array}$ \\
\hline & & \multirow[t]{2}{*}{ Dedicated server and network } & $\begin{array}{l}\text { All the features of server required for } \\
\text { efficiency }\end{array}$ \\
\hline & & & $\begin{array}{l}\text { All the features of network required for } \\
\text { efficiency }\end{array}$ \\
\hline & & \multirow{2}{*}{$\begin{array}{l}\text { Requires navigational and } \\
\text { narrative user interface Input } \\
\text { should be selective rather than } \\
\text { entering }\end{array}$} & $\begin{array}{l}\text { Te explanation displayed in user } \\
\text { interface }\end{array}$ \\
\hline & & & Navigational control used in interface \\
\hline
\end{tabular}

Table 7: Disadvantages of Mobile Banking Financial Transactions

\begin{tabular}{|c|c|c|c|}
\hline $\begin{array}{l}\text { Sl. } \\
\text { No }\end{array}$ & Issue & Factors affecting & Serious Ingredient Elements \\
\hline \multirow[t]{10}{*}{1} & \multirow[t]{10}{*}{ Security Issues } & $\begin{array}{l}\text { User level security acceptance } \\
\text { by the user }\end{array}$ & $\begin{array}{l}\text { Security aspect is questionable in } \\
\text { third party software }\end{array}$ \\
\hline & & \multirow[t]{4}{*}{ Network failure } & Single point of failure in hardware \\
\hline & & & Power problems or issues \\
\hline & & & Routing problems \\
\hline & & & Human error \\
\hline & & \multirow[t]{2}{*}{ Tampering of data } & Un-authorized access to data \\
\hline & & & Network failure \\
\hline & & \multirow{3}{*}{$\begin{array}{l}\text { Database failure or server } \\
\text { failure }\end{array}$} & Hardware failure \\
\hline & & & File corruption \\
\hline & & & File system damage \\
\hline \multirow[t]{12}{*}{2} & \multirow{12}{*}{$\begin{array}{l}\text { User friendly } \\
\text { issues }\end{array}$} & \multirow[t]{5}{*}{ Hardware and software cost } & Cost of RAM \\
\hline & & & Cost of Processor \\
\hline & & & Cost of the computer system \\
\hline & & & OS cost \\
\hline & & & Authentication system cost \\
\hline & & \multirow[t]{2}{*}{ Network cost } & Bandwidth cost \\
\hline & & & Data cost \\
\hline & & \multirow[t]{2}{*}{$\begin{array}{l}\text { High utilization of hardware } \\
\text { and software }\end{array}$} & $\begin{array}{l}\text { High utilization of memory and } \\
\text { processor }\end{array}$ \\
\hline & & & Space and time complexity \\
\hline & & $\begin{array}{l}\text { Complex backend design of } \\
\text { interface }\end{array}$ & $\begin{array}{l}\text { To design simple user interface for } \\
\text { user }\end{array}$ \\
\hline & & \multirow[t]{2}{*}{$24 \times 7$ service } & $\begin{array}{l}\text { High utilization of processor, and } \\
\text { memory }\end{array}$ \\
\hline & & & More power consumption \\
\hline \multirow[t]{2}{*}{3} & \multirow[t]{2}{*}{ Process Issues } & \multirow{2}{*}{$\begin{array}{l}\text { Requires separate programme } \\
\text { for } \\
\text { protection/safeguards }\end{array}$} & Management of the database \\
\hline & & & $\begin{array}{l}\text { Essentiality of the Database } \\
\text { protection }\end{array}$ \\
\hline
\end{tabular}

Krishna Prasad K. et al. (2018); www.srinivaspublication.com 


\begin{tabular}{|l|l|l|}
\hline & $\begin{array}{l}\text { Requires lock based } \\
\text { concurrency control system }\end{array}$ & $\begin{array}{l}\text { For acquiring isolation property of } \\
\text { the database transaction }\end{array}$ \\
\hline $\begin{array}{l}\text { Continuous availability of the } \\
\text { server increases cost }\end{array}$ & $\begin{array}{l}\text { Requirement of Ubiquitous } \\
\text { availability of the server }\end{array}$ \\
\cline { 2 - 4 } & $\begin{array}{l}\text { Requirement of efficiency of the } \\
\text { system }\end{array}$ \\
\hline & $\begin{array}{l}\text { Complex design of user } \\
\text { interface and programme } \\
\text { increases cost }\end{array}$ & $\begin{array}{l}\text { Requirement of effort-free } \\
\text { authentication process }\end{array}$ \\
\hline
\end{tabular}

\section{Advantages}

- Mobile banking is available 24/7 - anytime, anywhere, anyplace and anytime.

- We can exchange funds, pay bills, financial records balance, trade cash without intrusions/proposals from anybody, holding up time and speedy turnaround on requests.

- It delivers paperless statements directly into customers.

- The customers will get loyalty rewards in the form of points or discount coupons for transacting via the mobile banking application.

- Shares real-time updates on transactions executed, provides multi-level security features like OTP to registered mobile for authentication via the banking application.

- Allow the customers to get in touch with bank staff using the banking app.

- A different option like chat and call is available at any point of time for help and feedback.

- Limit human blunders, mechanize forms and wind up focused utilizing a decent cellphone based banking framework.

- Mobile banking is cost-effective, many banks offer paperless transaction service in less cost.

\section{Benefits}

- A ubiquitous service of banking transactions improves customer satisfaction, which internally influences on banking sector growths.

- Mobile Banking facility makes global expansion of the banking Financial Transactions.

- Mobile Banking helps to improve the brand name and reputation of the bank by providing fast and secured services to its stakeholders.

- Extension of advanced cell clients improves the matter of cell-phone service provider organizations.

- Frequent password change policy, and other high security measures like OTP enhances customer faith over banking financial transactions.

- High quality of services can be provided to users with the aid of 4G mobile communication technology.

\section{Constraints}

- Lack of new Security measures like Biometric recognition can reduce the number customer using mobile banking services especially in public sector banks in India.

- Lack of newer technology support can become hindrance for the expansion of mobile banking services.

- Slow network speed also can become another hindrance for the growth of mobile banking services.

\section{Disadvantages}

- Mobile Banking is not available on all mobile phone.

- Mobile Banking apps are necessary to do transactions, which are available on the high-end smartphone.

- Regular use of Mobile Banking may lead to extra charges levied by the bank for providing the service.

- Mobile banking users are at risk of getting fake SMS messages and scams.

- The loss of a mobile device often means that criminals can gain access to mobile banking PIN and other sensitive information. 
- Aside from this there are the standard dangers related with cell-phone based banking services incorporates hacking.

\section{Recommendations of the Study}

- Public sectors bank of India should adopt modern security measures like face based recognition or fingerprint biometric based recognition or any other biometric recognition system to enhance security features of mobile banking services.

- The transactions should not abort in between and incomplete transactions should not end with debit the money from user's accounts.

- Reimburse of money for failure transactions should take place within hours rather than within weeks.

- Speed of the transactions should increase to expand and improve mobile banking services in public sectors banks of India.

- Bank should minimize knowledge base input for authentication by using Biometric based authentication.

- User should able to authenticate without remembering anything.

- Authentication should happen by selecting rather than typing or entering knowledge base input.

- Bank should adopt new technologies like 4G/5G to enhance speed of transactions.

\section{CONCLUSION :}

Mobile banking (also known as M-banking) is one of the new, user-friendly and widely used concept in Electronic banking that is used to accomplish cashless financial transactions, fund transfer, credit applications and payment of bills, taxes etc. remotely through mobile devices like smartphones, PDAs, and tablets. Even though, the public sectors banks of India adopted mobile banking facility, they lack in speed and some security features. All the public sectors banks of India provides some common services like Fund transfer using IMPS, Fund transfer within the Bank accounts, Debit card management, Value added services and bill payment, Balance Enquiry and Mini Statement, SMS and Email Statement Registration, Aadhaar Seeding, Request for Cheque book, and View issued cheque status and Stop cheque payment. In this paper, we discussed and analyzed cell-phone banking money/financial transactions, using ABCD analysis and based on the analysis we likewise make a few proposals/recommendations to cell-phone enabled banking service contributor. This will encourage the scientist/researcher to find the gap between the traditional and digital method of financial transactions in India.

\section{REFERENCES :}

[1] Woerner, B., \& Howlader, M. (2001). Research Directions for Fourth Generation Wireless. In Enabling Technologies: Infrastructure for Collaborative Enterprises, 2001. WET ICE 2001. Proceedings. Tenth IEEE International Workshop, (pp. 60-61). IEEE.

[2] Kumar, S.N (2013). Emergence of 4G Technology in India and its Future Implications. International Journal of Engineering and Management Sciences, 4(2), 247-249.

[3] Dixit, S. (2002). Wireless IP and its challenges for the heterogeneous environment. Wireless Personal Communications, 22(2), 261-273.

[4] Krishna Prasad, K. and Aithal, P.S. (2017). A Study on Online Education Model Using Location Based Adaptive Mobile Learning. International Journal of Applied Engineering and Management $\mathrm{nm}$ Letters (IJAEML), 1(1), 36-44. DOI: http://doi.org/10.5281/zenodo. 820457

[5] Krishna Prasad, K. \& Aithal, P.S. (2017). A Customized and Flexible Ideal Mobile Banking System Using 5G Technology. International Journal of Management, Technology, and Social Sciences (IJMTS),1(1), 25-37. DOI: http://doi.org/10.5281/zenodo.820457

[6] Krishna Prasad K. \& Aithal, P.S. (2016). The Growth of 4G Technologies in IndiaChallenges and Opportunities. International Journal of Management, IT and 
Engineering (IJMIE), 6(1), 543 - 551. DOI

: http://doi.org/10.5281/zen odo.161130

[7] Krishna Prasad K. \& Aithal, P.S. (2016). Changing Perspectives of Mobile Information Communication Technologies towards Customized and Secured Services through 5G \& 6G. International Journal of Engineering Research and Modern Education (IJERME), 1(2), 210-224.

[8] Krishna Prasad, K. \& Aithal, P.S. (2016). An Online Comparative Study on 4G Technologies Service Providers in India. International Journal of Advanced Trends in Engineering and Technology (IJATET),1(1), 96-101. DOI: http://doi.org/10.5281/zenodo.240269.

[9] Krishna Prasad, K. and Aithal, P.S. (2016). Mobile System for Customized and Ubiquitous Learning by 4G/5G. International Journal of Management, IT and Engineering (IJMIE), 5(7), 63-71.

[10] Krishna Prasad, K. and P.S. Aithal (2015). Massive Growth of Banking Technology with the Aid Of 5G Technologies. International Journal of Management, IT and Engineering (IJMIE), 5(7), 616-627.

[11] Krishna Prasad K, \& Aithal P.S. (2014). An advanced Service Provision Model using 4G Technologies, Proceedings of National conference "Changing trends in Management, IT, and Social sciences", Manegma, 2014, Mangalore, ISBN No. 978-81-929306-0-2.

[12] Safeena, R., Date, H., Kammani, A., \& Hundewale, N. (2012). Technology adoption and Indian consumers: study on mobile banking. International Journal of Computer Theory and Engineering, 4(6), 1020.

[13] Amin, H., Hamid, M.R.A., Tanakinjal, G.H., \& Lada, S. (2006). Undergraduate attitudes and expectations for mobile banking. Journal of Internet Banking and Commerce, 11(3), 2006-12.
[14] Ivatury, G., \& Mas, I. (2008). The early experience with branchless banking. CGAP Focus Note, (46).

[15] Donner, J., \& Tellez, C.A. (2008). Mobile banking and economic development: Linking adoption, impact, and use. Asian journal of communication, 18(4), 318-332.

[16] Liu, Z., Min, Q., \& Ji, S. (2009, May). An empirical study odn mobile banking adoption: The role of trust. In Electronic Commerce and Security, 2009. ISECS'09. Second International Symposium on (Vol. 2, pp. 7-13). IEEE.

[17] Veijalainen, J., Terziyan, V., \& Tirri, H. (2006). Transaction management for mcommerce at a mobile terminal. Electronic Commerce Research and Applications, 5(3), 229-245.

[18] Shaikh, A.A. (2013). Mobile banking adoption issues in Pakistan and challenges ahead. J. Inst. Bankers Pak, 80(3), 12-15.

[19] Suoranta, M., \& Mattila, M. (2004). Mobile banking and consumer behaviour: New insights into the diffusion pattern. Journal of Financial Services Marketing, 8(4), 354366.

[20] Riivari, J. (2005). Mobile banking: A powerful new marketing and CRM tool for financial services companies all over Europe. Journal of Financial Services Marketing, 10(1), 11-20.

[21] Suoranta, M., Mattila, M., \& Munnukka, J. (2005). Technology-based services: a study on the drivers and inhibitors of mobile banking. International Journal of Management and Decision Making, 6(1), 33-46.

[22] Vijayan, P., Vignesen, P., \& Bala, S. (2005). Multimedia banking and technology acceptance theories. Journal of Internet Banking and Commerce, 10(1), 1-7.

[23] Lee, M. S., McGoldrick, P.J., Keeling, K.A., \& Doherty, J. (2003). Using ZMET to explore barriers to the adoption of 3G mobile banking services. International 
Journal of Retail \& Distribution Management, 31(6), 340-348.

[24] Thakur, R., \& Srivastava, M. (2014). Adoption readiness, personal innovativeness, perceived risk and usage intention across customer groups for mobile payment services in India. Internet Research, 24(3), 369-392.

[25] Nayak, N. I. T. I. N., Nath, V. I. K. A. S., \& Goel, N. A. N. C. Y. (2014). A study of adoption behaviour of mobile banking services by Indian consumers. International Journal of Research in Engineering \& Technology, 2(3), 2347-4599.

[26] Jain, Y. (2013). Mobile Banking: A Study on Adoption \& challenges in Southern Rajasthan, India. International Journal of Innovative Research and Development, 2(4), 902-914.

[27] Sathye, M. (1999). Adoption of Internet banking by Australian consumers: an empirical investigation. International Journal of bank marketing, 17(7), 324-334.

[28] Mattila, M. (2001). Essays on customers in the dawn of interactive banking. Jyväskylän Yliopisto.

[29] Aithal, P.S., Shailashree, V.T., Suresh Kumar, P.M. (2015). A New ABCD Technique to Analyze Business Models \& Concepts, International Journal of Management, IT and Engineering (IJMIE), 5(4), 409-423. DOI : http://doi.org/10.5281/zenodo.61652.

[30] Aithal, P.S. (2016). Study on ABCD Analysis Technique for Business Models, Business strategies, Operating Concepts \& Business Systems, International Journal in Management and Social Science, 4(1), 98115. DOI http://doi.org/10.5281/zenodo.161137.

[31] Aithal, P.S., Shailashree, V.T., \& Suresh Kumar, P.M. (2015). Application of ABCD Analysis Model for Black Ocean Strategy. International Journal of Applied Research (IJAR), 1(10), 331-337. DOI: http://doi.org/ 10.5281/zenodo.163424.
[32] Aithal, P.S., Shailashree, V.T., \& Suresh Kumar P.M., (2016). ABCD analysis of Stage Model in Higher Education. International Journal of Management, IT and Engineering (IJMIE), 6(1), 11-24. DOI: http://doi.org/10.5 281/zenodo.154233.

[33] Aithal, P.S., Shailashree, V.T., \& Suresh Kumar, P.M. (2016). Analysis of NAAC Accreditation System using ABCD framework. International Journal of Management, IT and Engineering (IJMIE), 6(1), 30-44. DOI: http://doi.org/10. 5281/zenodo.154272.

[34] Aithal, P.S., Shailashree, V.T., \& Suresh Kumar, P.M. (2016). Application of ABCD Analysis Framework on Private University System in India. International Journal of Management Sciences and Business Research (IJMSBR), 5(4), 159-170. DOI : http://doi.org/10.5281/zenodo.161111.

[35] Aithal, P.S., Shailashree, V.T., \& Suresh Kumar, P.M. (2016). The Study of New National Institutional Ranking System using ABCD Framework, International Journal of Current Research and Modern Education (IJCRME), 1(1), 389-402. DOI : http://doi.org/10.5281/zenodo.161077.

[36] Aithal, S., \& Aithal, P.S. (2016). ABCD analysis of Dye doped Polymers for Photonic Applications. IRA-International Journal of Applied Sciences, 4 (3), 358378. DOI: http://dx.doi.org/10.21013/j as.v4.n3.p1.

[37] Aithal, P.S., Shailashree, V. T. \& Suresh Kumar, P. M., (2016). Analysis of ABC Model of Annual Research Productivity using ABCD Framework. International Journal of Current Research and Modern Education (IJCRME), 1(1), 846-858. DOI : http://doi.org/10.5281/ zenodo.62022.

[38] Varun Shenoy, \& Aithal P.S., (2016). ABCD Analysis of On-line Campus Placement Model. IRA-International Journal of Management \& Social Sciences, 5(2), 227-244. DOI: http://dx.doi.org/10.21013/jmss .v5.n2.p3. 
[39] Aithal, P.S., Shailashree V.T. \& Suresh Kumar P.M. (2016). Factors \& Elemental Analysis of Six Thinking Hats Technique using ABCD Framework. International Journal of Advanced Trends in Engineering and Technology (IJATET), 1(1), 85-95. DOI

http://doi.org/10.5281/zenodo.240259.

[40] Aithal, P.S. \& Suresh Kumar, P.M. (2016). CCE Approach through ABCD Analysis of 'Theory A' on Organizational Performance. International Journal of Current Research and Modern Education (IJCRME) 1(1), 169-185. DOI: http://dx .doi.org/10.5281/zenodo.164704.

[41] Aithal, P.S. (2017). ABCD Analysis of Recently Announced New Research Indices. International Journal of Management, Technology, and Social Sciences (IJMTS), 2(1), 65-76. DOI: http://doi.org/10.5281/ zenodo. 583644.

[42] Aithal, P.S. (2017). Factor Analysis based on ABCD Framework on Recently Announced New Research Indices. International Journal of Management, Technology, and Social Sciences (IJMTS), 1(1), 82-94. DOI: http://dx.doi.org/10.5281/zenodo.584105.

[43] Aithal, P.S., (2017). ABCD Analysis as Research Methodology in Company Case Studies. International Journal of Management, Technology, and Social Sciences (IJMTS), 2(2), 40-54. DOI: http://dx.doi.org/10.5 281/zenodo.891621

[44] Aithal, Architha., Aithal, P.S. (2017). ABCD Analysis of Task Shifting-An optimum Alternative Solution to Professional Healthcare Personnel Shortage. International Journal of Health Sciences and Pharmacy (IJHSP), 1(2), 36-51. DOI: http://dx.doi.org/10.5281/ zenodo.1038975.

[45] Varun Shenoy \& Aithal, P.S., (2017). Quantitative ABCD Analysis of IEDRA Model of Placement Determination.
International Journal of Case Studies in Business, IT and Education (IJCSBE), 1(2), 103-113. DOI: http://dx.doi.o rg/10.5281/zenodo.1133691.

[46] Krishna Prasad, K. \& Aithal, P.S. (2018). ABCD Analysis of Fingerprint Hash Code, Password and OTP based Multifactor Authentication Model. Saudi Journal of Business and Management Studies, 3(1), 65-80. DOI: http://10.21276/sjbms.2018.3.1.10. 